\title{
PROBLEMATIKA PUSTAKAWAN DALAM MENULIS KARYA TULIS ILMIAH
}

\author{
Fahrizandi Abdan \\ Institut Agama Islam Negeri (IAIN) Pontianak, \\ Kalimantan Barat, Indonesia \\ fahrizandii@gmail.com
}

\begin{abstract}
This study studies the problem of writing scientific papers for librarians. The activity of writing scientific papers as one of the main elements of librarian activity is the element of professional development. For librarians, especially as beginners, writing activities become difficult activities, this is influenced by external factors such as situations and conditions that are not possible to write, as well as internal factors including a narrow scientific horizon and influential psychological factors. However, the effort that can be done in honing the ability to write scientific papers in a way of practice and regular practice is balanced by reading a lot, listening carefully, and writing a lot.
\end{abstract}

Keywords: Librarian, Professional Development, Scientific Writing

\begin{abstract}
Abstrak
Studi ini mempelajari persoalan menulis karya tulis ilmiah bagi pustakawan. Kegiatan menulis karya tulis ilmiah sebagai salah satu unsur utama kegiatan pustakawan yaitu unsur pengembangan profesi. Bagi pustakawan terutama sebagai penulis pemula, kegiatan menulis menjadi kegiatan yang sulit,
\end{abstract}


hal ini dipengaruhi selain faktor eksternal seperti situasi dan kondisi yang tidak memungkinkan untuk menulis, juga faktor internal di antaranya cakrawala keilmuan yang masih sempit serta faktor psikologis yang masih berpengaruh. Namun demikian, upaya yang dapat dilakukan dalam mengasah kemampuan menulis karya tulis ilmiah dengan cara latihan dan praktek yang teratur diimbangi dengan membaca yang banyak, mendengarkan dengan cermat, dan menulis yang banyak.

Kata kunci: Pustakawan, Pengembangan Profesi, Karya Tulis Ilmiah

\section{A. Pendahuluan}

Menulis sebagai suatu cara untuk berkomunikasi secara tidak langsung. Menulis bagian dari empat komponen keterampilan berbahasa, adapun empat komponen, yaitu: 1) keterampilan menyimak (listening skil), 2) keterampilan berbicara (speaking skill), 3) keterampilan membaca (reading skill), dan 4) keterampilan menulis (writing skill). Keempat keterampilan tersebut pada dasarnya merupakan satu kesatuan, merupakan catur-tunggal. ${ }^{1}$

Keterampilan menulis bersifat mekanistis. Keterampilan itu tidak akan dikuasai hanya melalui teori saja namun harus dilaksanakan melalui latihan dan praktik yang teratur. Kemampuan menulis adalah kesanggupan atau kecakapan seseorang dalam mengungkapkan perasaan yang berkenaan dengan suatu pokok masalah secara tegas, lugas, dan tuntas dengan menggunakan bahasa tulis. ${ }^{2}$.

Tentu saja fungsi utama dari tulisan adalah sebagai alat komunikasi tidak langsung. Menulis juga sangat penting bagi pendidikan karena memudahkan para pelajar berpikir kritis, memperdalam daya tanggap, memecahkan masalah yang dihadapi,

${ }^{1}$ Henry Guntur Tarigan, Menulis Sebagai Suatu Keterampilan Berbahasa (Angkasa, 2008), 1.

2 Aceng Hasani, Ihwal Menulis (Untirta Press, 2005), 2. 
menyusun urutan bagi pengalaman. ${ }^{3}$. Dan manfaat lain menjadi penulis, sastrawan besar Pramoedya Ananta Toer, penulis novel tetralogi "Bumi Manusia" menyatakan, bahwa sepandai apa pun seorang manusia, apabila dalam hidupnya dia tidak menuliskan kepandaiannya, maka begitu ia meninggal dunia, maka karyanya kurang dikenang dan diwarisi generasi setelahnya. Namun, apabila ia mau menuliskan kepandaian atau temuan-temuannya itu, maka kematiannya tidak akan menghentikan orang yang masih hidup untuk mengapresiasi karya-karyanya, serta mengenang namanya, bahkan mungkin sampai akhir zaman. ${ }^{4}$

Sebenarnya, kegiatan menulis sering dilakukan hampir dalam kegiatan sehari-hari terutama yang berkaitan dengan kegiatan komunikasi tidak langsung, termasuk profesi pustakawan telah menjadikan kegiatan menulis terutama menulis karya tulis ilmiah sebagai kegiatan utama pustakawan. Tentu saja, kegiatan menulis karya tulis ilmiah memberikan manfaat langsung kepada pustakawan dalam mengasah kemampuan berpikir sekaligus menambah wawasan ilmu pengetahuan serta dapat meningkatkan karier dan eksistensi pustakawan.

Bagi pustakawan kegiatan menulis karya tulis ilmiah belum menjadi pilihan utama untuk meningkatkan kompetensi pustakawan. Ironisnya, menulis karya tulis ilmiah menjadi beban bagi pustakawan, padahal pustakawan setiap saat berhubungan dengan koleksi yang memuat berbagai informasi, jika informasi dibaca dan ditulis serta disebarluaskan kembali dalam perspektif pustakawan akan lebih menarik. Namun hingga saat ini, masih sedikit karya tulis ilmiah yang dihasilkan oleh pustakawan, bahkan terkesan pustakawan kurang produktif dan tidak kreatif dalam menulis.

Meskipun demikian, menulis karya tulis ilmiah bukanlah suatu aktifitas yang dapat dilakukan secara spontanitas. Kegiatan

3 Tarigan, Menulis Sebagai Suatu Keterampilan Berbahasa, 22-23.

4 Djatmika, Menjadi Penulis Untuk Pencerahan Demokrasi (Malang: Bayumedia Publishing, 2004), 1. 
menulis memerlukan banyak latihan yang harus dilakukan secara berulang-ulang secara teratur sehingga menghasilkan karya tulis ilmiah yang layak dipublikasikan.

Tulisan ini, menjelaskan persoalan menulis karya tulis ilmiah. problematika yang dimaksud disini adalah segala permasalahan, hambatan, dan kesulitan yang dialami oleh pustakawan yang akan dan atau sedang menulis karya tulis ilmiah. Selanjutnya, langkah-langkah untuk mengatasi kesulitan menulis tersebut, sehingga pustakawan dapat menghasilkan karya tulis ilmiah dengan baik.

\section{B. Pembahasan}

\section{Hakikat dan Tugas Pustakawan}

Pustakawan adalah seseorang yang memiliki kompetensi yang diperoleh melalui pendidikan dan/atau pelatihan kepustakawanan serta mempunyai tugas dan tanggung jawab untuk melaksanakan pengelolaan dan pelayanan perpustakaan. ${ }^{5}$

Kompetensi yang harus dimiliki pustakawan mencakup yaitu kompetensi profesional dan kompetensi personal. Kompetensi profesional mencakup aspek pengetahuan, keahlian, dan sikap kerja. Sedangkan kompetensi personal mencakup aspek kepribadian dan interaksi sosial. ${ }^{6}$

Jabatan fungsional pustakawan adalah jabatan yang mempunyai ruang lingkup, tugas, tanggung jawab, wewenang, dan hak untuk melaksanakan kegiatan kepustakawanan, yang berkedudukan sebagai pelaksana teknis di bidang kepustakawanan, merupakan jabatan karier yang diduduki oleh PNS. ${ }^{7}$

\footnotetext{
${ }^{5}$ Indonesia, Undang-Undang Republik Indonesia Nomor 43 Tahun 2007 Tentang Perpustakaan (Perpustakaan Nasional, 2007).

6 "Peraturan Pemerintah Republik Indonesia Nomor 24 Tahun 2014 Tentang Pelaksanaan Undang-Undang Nomor 43 Tahun 2007 Tentang Perpustakaan," n.d.

7 "Peraturan Menteri Pendayagunaan Aparatur Negara Dan Reformasi Birokrasi Republik Indonesia Nomor 9 Tahun 2014 Tentang Jabatan Fungsional Pustakawan Dan Angka Kreditnya," n.d.
} 
Dalam mewujudkan kompetensi tersebut dirumuskan tugas pokok jabatan fungsional pustakawan yaitu melaksanakan kegiatan di bidang kepustakawanan yang meliputi pengelolaan perpustakaan, pelayanan perpustakaan, dan pengembangan sistem kepustakawanan. ${ }^{8}$

Adapun unsur kegiatan pustakawan yang dinilai terdiri atas unsur utama dan unsur penunjang yang masing-masing, meliputi:

a. Unsur Utama, terdiri atas:

1) Pendidikan

2) Pengelolaan perpustakaan

3) Pelayanan perpustakaan

4) Pengembangan sistem kepustakawanan

5) Pengembangan profesi

b. Unsur Penunjang

1) Pengajar/pelatih pada diklat fungsional/teknis bidangkepustakawanan

2) Peran serta dalam seminar/lokakarya/konferensi dibidang kepustakawanan

3) Keanggotaan dalam organisasi profesi

4) Keanggotaan dalam tim penilai

5) Perolehan penghargaan/tanda jasa

6) Perolehan gelar/ijazah kesarjanaan lainnya. ${ }^{9}$

Dari kelima unsur utama kegiatan pustakawan, aspek kegiatan menulis karya tulis ilmiah terdapat pada unsur kegiatan utama yaitu pengembangan profesi. Bahkan menjadi syarat

${ }^{8}$ R. I. Perpustakaan Nasional, "Peraturan Bersama Kepala Perpustakaan Nasional Republik Indonesia Dan Kepala Badan Kepegawaian Negara Nomor 8 Tahun 2014 Nomor 32 Tahun 2014 Tentang Ketentuan Pelaksanaan Peraturan Menteri Pendayagunaan Aparatur Negara Dan Reformasi Birokrasi Republik Indonesia Nomor 9 Tahun 2014 Tentang Jabatan Fungsional Pustakawan Dan Angka Kreditnya," 2014.

9 R. I. Perpustakaan Nasional, "Peraturan Kepala Perpustakaan Nasional Republik Indonesia Nomor 11 Tahun 2015 Tentang Petunjuk Teknis Jabatan Fungsional Pustakawan Dan Angka Kreditnya," 2015. 
pustakawan ahli untuk kenaikan jenjang pangkat/jabatan yang lebih tinggi, sebagaimana dijelaskan dalam Peraturan Bersama Kepala Perpustakaan Nasional Republik Indonesia Dan Kepala Badan Kepegawaian Negara Nomor 8 Tahun 2014 Nomor 32 Tahun 2014 Tentang Ketentuan Pelaksanaan Peraturan Menteri Pendayagunaan Aparatur Negara Dan Reformasi Birokrasi RI. Adapun persyaratan angka kredit pengembangan profesi untuk pustakawan ahli sebagi berikut:

Tabel 1. Angka Kredit Pengembangan Profesi Pustakawan Ahli

\begin{tabular}{|c|c|c|}
\hline No & $\begin{array}{l}\text { Pustakawan Ahli Berdasarkan } \\
\text { Pangkat Dan Golongan }\end{array}$ & $\begin{array}{l}\text { Syarat Angka Kredit Dari } \\
\text { Pengembangan Profesi }\end{array}$ \\
\hline 1. & $\begin{array}{l}\text { Pustakawan Ahli Pertama, } \\
\text { pangkat Penata Muda Tingkat } \\
\text { I, golongan ruang III/b yang } \\
\text { akan naik jabatan dan pangkat } \\
\text { menjadi Pustakawan Ahli Muda } \\
\text { pangkat Penata, golongan ruang } \\
\text { III/c, }\end{array}$ & $\begin{array}{l}\text { Paling kurang } 2 \text { (dua) } \\
\text { angka kredit }\end{array}$ \\
\hline 2. & $\begin{array}{l}\text { Pustakawan Ahli Muda, pangkat } \\
\text { Penata, golongan ruang III/c } \\
\text { yang akan naik pangkat menjadi } \\
\text { Penata Tingkat I, golongan ruang } \\
\text { III/d, }\end{array}$ & $\begin{array}{l}\text { Paling kurang } 4 \text { (empat) } \\
\text { angka kredit }\end{array}$ \\
\hline 3. & $\begin{array}{l}\text { Pustakawan Ahli Muda, pangkat } \\
\text { Penata Tingkat I, golongan ruang } \\
\text { III/d yang akan naik jabatan dan } \\
\text { pangkat menjadi Pustakawan } \\
\text { Ahli Madya, pangkat Pembina, } \\
\text { golongan ruang IV/a, }\end{array}$ & $\begin{array}{l}\text { Paling kurang } 6 \text { (enam) } \\
\text { angka kredit }\end{array}$ \\
\hline 4. & $\begin{array}{l}\text { Pustakawan Ahli Madya, pangkat } \\
\text { Pembina, golongan ruang IV/a } \\
\text { yang akan naik pangkat menjadi } \\
\text { Pembina Tingkat I, golongan } \\
\text { ruang IV/b, }\end{array}$ & $\begin{array}{l}\text { Paling kurang } 8 \text { (delapan) } \\
\text { angka kredit }\end{array}$ \\
\hline
\end{tabular}




\begin{tabular}{lllll}
\hline 5. & Pustakawan Ahli Madya, \\
pangkat Pembina Tingkat I, & $\begin{array}{l}\text { Paling } \\
\text { (sepuluh) }\end{array}$ & & \\
golongan ruang IV/b yang akan & & & \\
naik pangkat menjadi Pembina & & & \\
Utama Muda, golongan ruang & & & & \\
IV/c, & & & & \\
\hline 6. & Pustakawan Ahli Madya, Paling kurang 12 (dua \\
pangkat Pembina Utama Muda, belas) angka kredit & \\
golongan ruang IV/c yang & & & \\
akan naik jabatan dan pangkat & & & \\
menjadi Pustakawan Utama, & & & \\
pangkat Pembina Utama Madya, \\
golongan ruang IV/d,
\end{tabular}

Sumber: Peraturan Bersama Kepala Perpustakaan Nasional Republik Indonesia Dan Kepala Badan Kepegawaian Negara Nomor 8 Tahun 014 Nomor 32 Tahun 2014 Tentang Ketentuan Pelaksanaan Peraturan Menteri Pendayagunaan Aparatur Negara Dan Reformasi Birokrasi RI

Memang unsur pengembangan profesi secara tegas disyaratkan kepada pustakawan tingkat keahlian, namun sebenarnya kegiatan pengembangan profesi juga dapat dilakukan oleh pustakawan tingkat keterampilan. Tentu saja, syarat angka kredit dari unsur pengembangan profesi menjadi motivasi bagi pustakawan untuk mengasah kemampuan menulis karya tulis ilmiah dan bahkan menjadi peluang bagi pustakawan yang telah mahir dalam menulis karya tulis ilmiah sehingga mengalami kemudahan dalam kenaikan pangkat dan jabatannya. Namun sebaliknya, bagi pustakawan yang kurang terampil menulis karya tulis ilmiah akan mengalami kesulitan dan bahkan dapat menjadi penghambat dalam meningkatkan kariernya. 


\section{Pengembangan Profesi Pustakawan}

Pengembangan profesi adalah pengembangan pengetahuan, keahlian, keterampilan, sikap dan bakat yang bermanfaat untuk profesi pustakawan dalam melaksanakan tugas kepustakawanan. Pengembangan profesi termasuk unsur utama yang dinilai angka kreditnya, meliputi sub unsur: pembuatan karya tulis/karya ilmiah di bidang kepustakawanan; penerjemahan/penyaduran buku dan/ atau bahan lain di bidang kepustakawanan; dan penyusunan buku pedoman/ketentuan pelaksanaan/ketentuan teknis. ${ }^{10}$

Karya tulis/karya ilmiah adalah tulisan hasil pokok pikiran, pengembangan, dan hasil kajian/penelitian bidang kepustakawanan yang disusun oleh Pustakawan baik perorangan atau kelompok. ${ }^{11}$

a. Pembuatan Karya Tulis/Karya Ilmiah di Bidang Kepustakawanan

Untuk membuat sebuah karya tulis/karya ilmiah di bidang kepustakawanan harus memenuhi syarat sebagai berikut:

1) Subjek kajian di bidang kepustakawanan

2) Langkah penulisan menggunakan metode ilmiah, yang ditandai dengan:

a) Argumentasi teoritik yang benar, valid dan relevan;

b) Dukungan fakta empiris;

c) Analisis kajian yang mempertautkan antara argumentasi teoritik dengan fakta empiris terhadap permasalahan yang dikaji.

3) Penyajiannya sesuai dan memenuhi persyaratan sebagai suatu tulisan ilmiah, yang ditandai dengan:

${ }_{10}$ Perpustakaan Nasional, "Peraturan Bersama Kepala Perpustakaan Nasional Republik Indonesia Dan Kepala Badan Kepegawaian Negara Nomor 8 Tahun 2014 Nomor 32 Tahun 2014 Tentang Ketentuan Pelaksanaan Peraturan Menteri Pendayagunaan Aparatur Negara Dan Reformasi Birokrasi Republik Indonesia Nomor 9 Tahun 2014 Tentang Jabatan Fungsional Pustakawan Dan Angka Kreditnya."

11 "Peraturan Menteri Pendayagunaan Aparatur Negara Dan Reformasi Birokrasi Republik Indonesia Nomor 9 Tahun 2014 Tentang Jabatan Fungsional Pustakawan Dan Angka Kreditnya." 
a) Isi sajian berada pada lingkup keilmuan;

b) Penulisan dilakukan secara cermat, akurat, logis dan menggunakan sistematika yang umum dan jelas;

c) Tidak bersifat subjektif, emosional, atau memuat fakta tidak rasional.Standar kerangka penulisan sesuai dengan pedoman penulisan karya tulis ilmiah. $^{12}$

b. Sub Unsur Kegiatan Pengembangan Profesi dan Angka Kreditnya

Setiap unsur kegiatan pengembangan profesi memiliki kegiatan dan angka kredit yang berbeda pula. Adapun, sub unsur kegiatan pengembangan profesi terdiri atas butir kegiatan dan angka kreditnya sebagai berikut:

1) Membuat karya tulis/karya ilmiah hasil penelitian, pengkajian, survei, dan evaluasi di bidang kepustakawanan yang dipublikasikan dalam bentuk:

a) Buku yang diterbitkan dan diedarkan secara nasional (semua jenjang keahlian: angka kredit 12,5)

Kegiatan membuat laporan hasil penelitian, pengkajian, survei, dan evaluasi di bidang kepustakawanan yang disajikan dalam bentuk buku berisi paling kurang 15000 kata atau lebih kurang 49 halaman (tidak termasuk halaman judul, ilustrasi, dan daftar pustaka), diterbitkan oleh instansi pemerintah atau swasta, memiliki ISBN, dan diedarkan secara nasional.

b) Majalah ilmiah (semua jenjang keahlian: angka kredit 6)

${ }_{12}$ Perpustakaan Nasional, "Peraturan Bersama Kepala Perpustakaan Nasional Republik Indonesia Dan Kepala Badan Kepegawaian Negara Nomor 8 Tahun 2014 Nomor 32 Tahun 2014 Tentang Ketentuan Pelaksanaan Peraturan Menteri Pendayagunaan Aparatur Negara Dan Reformasi Birokrasi Republik Indonesia Nomor 9 Tahun 2014 Tentang Jabatan Fungsional Pustakawan Dan Angka Kreditnya." 
Kegiatan membuat karya tulis berupa laporan hasil penelitian, pengkajian, survei, dan evaluasi di bidang kepustakawanan dalam bentuk makalah paling kurang 5000 kata, dimuat dalam majalah ilmiah yang diterbitkan oleh organisasi profesi, instansi pemerintah atau swasta, dan/atau majalah lain yang memiliki ISSN.

2) Membuat karya tulis/karya ilmiah hasil penelitian, pengkajian, survei dan evaluasi di bidang kepustakawanan yang tidak dipublikasikan dalam bentuk:

a) Buku (semua jenjang keahlian: angka kredit 8)

Kegiatan membuat karya tulis berupa laporan hasil penelitian, pengkajian, survei, dan evaluasi di bidang kepustakawanan dalam bentuk buku berisi paling kurang 15000 kata atau lebih kurang 49 halaman (tidak termasuk halaman judul, ilustrasi, dan daftar pustaka), yang dicetak dalam jumlah terbatas untuk kalangan tertentu sebagai bentuk pertanggungjawaban kegiatan dan didokumentasikan di perpustakaan.

b) Makalah (semua jenjang keahlian: angka kredit 4)

Kegiatan membuat karya tulis berupa laporan hasil penelitian, pengkajian, survei, dan evaluasi dibidang kepustakawanan dalam bentuk makalah paling kurang 3500 kata, yang digandakan dalam jumlah terbatas untuk kalangan tertentu sebagai bentuk pertanggungjawaban kegiatan, dan didokumentasikan di perpustakaan.

3) Membuat karya tulis/karya ilmiah berupa tinjauan atau ulasan ilmiah dengan gagasan sendiri di bidang kepustakawanan yang dipublikasikan dalam bentuk: 
a) Buku yang diterbitkan dan diedarkan secara nasional (semua jenjang keahlian: angka kredit 8)

Kegiatan membuat karya tulis ilmiah yang membahas tentang kepustakawanan atau meninjau ulang hasil karya yang sudah ada melalui identifikasi, deskripsi permasalahan, analisis masalah, dan saran pemecahannya. Karya tulis tersebut dalam bentuk buku yang berisi paling kurang 15000 kata atau lebih kurang 49 halaman (tidak termasuk halaman judul, ilustrasi, dan daftar pustaka), diterbitkan oleh instansi pemerintah atau swasta, memiliki ISBN, dan diedarkan secara nasional.

b) Majalah ilmiah yang diakui secara nasional (semua jenjang keahlian: angka kredit 4)

Kegiatan membuat karya tulis ilmiah yang membahas tentang kepustakawanan atau meninjau ulang hasil karya yang sudah ada, berdasarkan analisis dan sintesis data atau hasil kajian, atau pemikiran baru yang belum pernah ditulis dan dipublikasikan orang lain dalam bentuk makalah paling kurang 3500 kata dalam format baku meliputi: judul, abstrak, penutup, dan daftar pustaka yang dimuat dalam majalah ilmiah yang diterbitkan oleh organisasi profesi, instansi pemerintah atau swasta, dan/atau majalah lain yang memiliki ISSN.

4) Membuat karya tulis/karya ilmiah berupa tinjauan atau ulasan ilmiah dengan gagasan sendiri dalam bidang kepustakawanan yang tidak dipublikasikan dalam bentuk:

a) Buku (semua jenjang keahlian: angka kredit 7)

Kegiatan membuat karya tulis ilmiah yang membahas tentang kepustakawanan, atau meninjau ulang hasil karya yang sudah ada dalam bentuk 
buku yang berisi paling kurang 15000 kata atau lebih kurang 49 halaman (tidak termasuk halaman judul, ilustrasi, dan daftar pustaka), yang dicetak dalam jumlah terbatas sebagai bentuk pertanggungjawaban kegiatan, dan didokumentasikan di perpustakaan.

a) Makalah (semua jenjang keahlian: angka kredit 3,5) Kegiatan membuat karya tulis ilmiah yang membahas tentang kepustakawanan, atau meninjau ulang hasil karya yang sudah ada berdasarkan analisis dan sintesis data atau hasil kajian, atau pemikiran baru yang belum pernah ditulis dan dipublikasikan orang lain paling kurang 3000 kata, dalam format baku meliputi: judul, abstrak, pendahuluan, isi pokok, penutup,dan daftar pustaka, digandakan dalam jumlah terbatas untuk kalangan tertentu sebagai bentuk pertanggungjawaban kegiatan, dan didokumentasikan di perpustakaan.

5) Membuat tulisan ilmiah populer di bidang kepustakawanan yang disebarluaskan melalui media massa (semua jenjang keahlian: angka kredit 2)

Kegiatan membuat karya tulis ilmiah yang menyajikan pandangan, gagasan, komentar atau ulasan terhadap suatu permasalahan di bidang perpustakaan yang ditulis dalam kerangka isi yang lebih bebas bertujuan agar menarik dan mudah dipahami oleh pembacanya serta diterbitkan di surat kabar/majalah/buletin/jurnal termasuk di dalamnya editorial.

6) Menyampaikan prasaran berupa tinjauan, gagasan dan/ atau ulasan ilmiah di bidang kepustakawanan pada pertemuan ilmiah (semua jenjang keahlian: angka kredit 3)

Kegiatan membuat karya tulis ilmiah yang membahas satu pokok bahasan yang merupakan tinjauan atau ulasan ilmiah dari berbagai pendapat atau sumber 
informasi tertulis di bidang kepustakawanan. Makalah bersifat deskriptif informatif yang ditulis dalam format tertentu paling kurang 3000 kata, dan disampaikan pada pertemuan ilmiah, diklat dan sejenisnya.

7) Penyaduran buku dan/atau bahan-bahan lain di bidang kepustakawanan

Kegiatan membuat karya tulis hasil alih bahasa suatu tulisan/karya di bidang kepustakawanan dari bahasa tertentu ke bahasa lain.

Saduran adalah karya tulis yang berupa terjemahan bebas di bidang kepustakawanan dengan cara meringkas atau menyederhanakan maupun mengembangkan tulisan tanpa mengubah pokok pikiran karya aslinya. Terjemahan/saduran harus mengikuti kaidah bahasa Indonesia yang baik dan benar.

Sub unsur ini terdiri atas butir kegiatan sebagai berikut:

a) Menerjemahkan/menyadur buku di bidang kepustakawanan yang dipublikasikan, dalam bentuk:

1. Buku yang diterbitkan dan diedarkan secara nasional (semua jenjang keahlian: angka kredit 7)

Kegiatan membuat karya tulis hasil alih bahasa suatu tulisan/karya dari bahasa tertentu ke bahasa lain, atau karya tulis hasil terjemahan bebas tanpa mengubah pokok pikiran karya aslinya ditulis dalam bentuk buku, diterbitkan oleh suatu lembaga penerbit, dan diedarkan untuk mendukung kegiatan kepustakawanan.

2. Majalah ilmiah yang diakui oleh instansi yang berwenang (semua jenjang keahlian: angka kredit 3,5)

Kegiatan membuat karya tulis hasil alih bahasa suatu tulisan/karya dari bahasa tertentu ke 
bahasa lain, atau karya tulis hasil terjemahan bebas tanpa mengubah pokok pikiran karya aslinya yang disajikan dalam bentuk makalah paling kurang 2000 kata dimuat dalam majalah ilmiah, diterbitkan oleh organisasi profesi, instansi pemerintah/swasta atau majalah lain yang memiliki ISSN. Apabila topik terjemahan/ saduran di luar bidang kepustakawanan, harus terkait dengan subjek utama instansi tempat pustakawan bekerja yang diperkuat dengan surat tugas.

b) Menerjemahkan/menyadur buku di bidang kepustakawanan yang tidak dipublikasikan, dalam bentuk:

1. Buku (semua jenjang keahlian: angka kredit 3) Kegiatan membuat karya tulis hasil alih bahasa suatu tulisan/karya dari bahasa tertentu ke bahasa lain, atau karya tulis hasil terjemahan bebas tanpa mengubah pokok pikiran karya aslinya yang ditulis dalam bentuk buku, yang dicetak dalam jumlah terbatas untuk kalangan tertentu sebagai bentuk pertanggungjawaban

2. Makalah (semua jenjang keahlian: angka kredit 1,5)

Kegiatan membuat karya tulis hasil alih bahasa suatu tulisan/karya dari bahasa tertentu ke bahasa lain, atau karya tulis hasil terjemahan secara bebas tanpa mengubah pokok pikiran karya tulis aslinya yang ditulis dalam bentuk makalah paling kurang 1500 kata yang dicetak dalam jumlah terbatas untuk kalangan tertentu sebagai bentuk pertanggungjawaban kegiatan dan didokumentasikan di perpustakaan. Apabila topik terjemahan/saduran di luar bidang kepustakawanan, harus terkait dengan subjek 
utama instansi tempat pustakawan bekerja yang diperkuat dengan surat tugas.

8) Membuat abstrak tulisan di bidang kepustakawanan yang dimuat dalam penerbitan (semua jenjang keahlian: angka kredit 2)

Kegiatan membuat karya tulis yang berisi pandangan, gagasan, komentar atau ulasan mengenai koleksi literatur sekunder yang bertujuan untuk mengembangkan layanan teknis dan layanan pemustaka. ${ }^{13}$

\section{Hakikat Menulis Karya Tulis Ilmiah}

\section{a. Pengertian Karya Tulis Ilmiah}

Menulis adalah proses mengutarakan pikiran, perasaan, penginderaan, hayalan, kemauan, keyakinan, dan pengalaman yang disusun dengan lambang-lambang grafik secara tertulis untuk tujuan komunikasi. ${ }^{14}$

Pendapat lain menyatakan, menulis adalah menurunkan atau melukiskan lambang-lambang grafik yang menggambarkan suatu bahasa yang dipahami oleh seseorang, sehingga orang lain dapat membaca lambang-lambang grafik tersebut kalau mereka memahami bahasa dan lambang grafik tersebut. ${ }^{15}$

Dari pengertian diatas, disimpulkan bahwa menulis adalah proses mengutarakan pikiran, perasaan, penginderaan, hayalan, kemauan, keyakinan, dan pengalaman yang disusun dengan lambang-lambang grafik secara tertulis untuk tujuan komunikasi sehingga dapat dipahami oleh seseorang.

Sedangkan, karya tulis ilmiah terdiri dari kata majemuk yaitu karya tulis dan ilmiah. Yang dimaksud dengan karya tulis adalah hasil dari suatu kegiatan menulis. Artinya, seluruh hasil perbuatan menulis disebut dengan karya tulis. Sedangkan

${ }_{13}$ Perpustakaan Nasional, "Peraturan Kepala Perpustakaan Nasional Republik Indonesia Nomor 11 Tahun 2015 Tentang Petunjuk Teknis Jabatan Fungsional Pustakawan Dan Angka Kreditnya."

${ }^{14}$ Hasani, Ihwal menulis, 2.

15 Tarigan, Menulis Sebagai Suatu Keterampilan Berbahasa, 22. 
ilmiah adalah segala sesuatu yang bersifat keilmuan. Ilmu adalah pengetahuan yang telah teruji kebenarannya dilakukan secara rasional atau secara empiris melalui metode-metode ilmiah. Karya tulis ilmiah adalah karya tulis yang bersifat keilmuan yang disusun secara sistematis menurut kaedah-kaedah tertentu berdasarkan hasil berfikir ilmiah dan metode ilmiah. ${ }^{16}$

Kategori sebagai karya tulis ilmiah adalah makalah, paper, artikel, skripsi, tesis, disertasi, dan laporan penelitian, karena dikembangkan dengan menggunakan metode ilmiah.

Makalah adalah karya tulis ilmiah yang ditulis untuk memenuhi tugas-tugas perkuliahan atau untuk seminar. Paper adalah karya tulis ilmiah yang ditulis untuk unjuk suatu pekerjaan. Penelitian ilmiah adalah karya tulis yang lebih ditujukan untuk mengembangkan ilmu atau menguji kebenaran ilmu. Skripsi, tesis, disertasi, dan laporan penelitian merupakan karya tulis sebagai hasil dari suatu penelitian. ${ }^{17}$

Artikel adalah karya tulis yang dirancang untuk dimuat dalam jurnal atau buku kumpulan artikel yang ditulis dengan tata cara ilmiah dan mengikuti pedoman atau konversi ilmiah yang telah disepakati atau ditetapkan. Dari sistematika penulisan dan dan isinya, artikel dapat dikelompokkan menjadi suatu macam, yaitu artikel hasil penelitian dan artkel nonpenelitian. Makalah adalah karya tulis yang memuat pemikiran tentang suatu masalah atau topik tertentu yang ditulis secara sistematis dan runtut dengan disertasi analisis yang logis dan objektif. Makalah ditulis untuk memenuhi tugas terstruktur yang diberikan oleh dosen atau diulis atas inisiatif sendir untuk disajikan dalam forum ilmiah. Laporan penelitian adalah karya tulis yang berisi paparan tentang proses dan hasil-hasil yang diperoleh dari suatu kegiatan penelitian. ${ }^{18}$

\footnotetext{
${ }^{16}$ Gani, E, Komponen-Komponen Karya Tulis Ilmiah (Bandung: Pustaka Reka Cipta, 2013), 2.

17 Gani, E, 2.

18 Tanjung, Bahdin Nur and Ardial, Pedoman Penulisan Karya Ilmiah (Proposal, Skipsi, Dan Tesis) Dan Mempersiapkan Diri Menjadi Penulis Artikel Ilmiah (Jakarta: Kencana, 2005), 7.
} 
Derajat keilmiahan suatu karya tulis ilmiah diklasifikasikan atas empat tingkat: ${ }^{19}$

1) Frontier science, karya tulis ilmiah yang dihasilkan untuk mendapatkan pengetahuan baru dengan cara yang kurang terukur, dengan pemikiran yang sederhana dan belum dicetak atau dipublikasikan.

2) Primary literature, karya tulis yang sudah dicetak atau dipublikasikan tetapi belum sepenuhnya sebagai sumber pengetahun ilmiah hanya sebatas informasi untuk dibaca secara luas.

3) Secondary literature, karya tulis yang sudah dipublikasikan, mulai menarik minat banyak orang, mulai diperhitungkan sebagai bahan kutipan.

4) Tertiary literature atau textbook science, karya tulis ilmiah yang sudah menjadi textbook dan kebenarannya menjadi seakan absolut, sehingga dapat menjadi referensi atau materi pengajaran. Jenjang ini berupa monograph, review article, dan graduate textbook.

Karya tulis dianggap karya tulis ilmiah jika mempunyai ciri-ciri sebagai berikut:

1) Objektif, mengungkapkan segala sesuatu seperti apa adanya.

2) Netral, setiap pernyataan, pengungkapan, informasi atau penilaian yang bebas dari kepentingan-kepentingan tertentu.

3) Sistematis, pola penyajian yang bersifat baku dengan menyajikan secara berurutan.

4) Logis, kelogisan mengacu kepada pola penalaran yang digunakan.

${ }^{19}$ Gani, E, Komponen-Komponen Karya Tulis Ilmiah, 3-4. 
5) Menyajikan fakta, setiap pernyataan, uraian, atau simpulan dalam karya ilmiah harus bersifat faktual berdasarkan fakta dan data. ${ }^{20}$

\section{b. Kendala Menulis Karya Tulis Ilmiah}

Setiap orang mempunyai derajat kesulitan kemampuan menulis yang berbeda, namun secara umum kekuranganmampuan berbahasa itu, khususnya dalam keterampilan menulis, disebabkan oleh beberapa faktor. Banyak orang memiliki ide tetapi sulit mengeluarkan ide itu secara tertulis. Kesulitan itu karena kurang terlatih menuliskan ide. Tidak sedikit orang juga mampu mengeluarkan ide secara tertulis, tetapi yang bersangkutan tidak mau mempublikasikan tulisannya dengan alasan takut ditertawakan orang lain. ${ }^{21}$

Selain faktor eksternal seperti situasi dan kondisi yang tidak memungkinkan untuk menulis, juga dipengaruhi oleh faktor internal di antaranya cakrawala keilmuan yang masih sempit dan faktor psikologis yang masih dominan berpengaruh. Adapun faktor psikologis yang dialaminya di antaranya adalah: a) Merasa diri tidak mampu untuk menulis, b) Takut salah atau disepelekan orang lain, c) Tidak berani mengambil resiko, d) Penyakit malas menulis, e) Ada anggapan bahwa gagasan cukup dituangkan dengan lisan, f) Menutup diri dari pengalaman dan gagasan baru, g) Merasa cukup menjadi konsumen. ${ }^{22}$

Dari pendapat di atas, bahwa kendala menulis dapat dikelompok ke dalam dua faktor, yaitu faktor internal dan faktor eksternal. Faktor internal kendala menulis karya tulis ilmiah mencakup kurangnya motivasi, tidak memiliki ide, tidak percaya diri, kurang fokus, wawasan yang sempit, tidak berbakat, kurang menguasai kebahasaan, merasa puas sebagai konsumen. Sedangkan

${ }^{20}$ Gani, E, 4-5.

${ }^{21}$ Hasani, Ihwal menulis, 18.

22 Djuharie, O. Setiawan and Suherli, Panduan Membuat Karya Tulis : Resensi, Laporan Buku, Skripsi, Tesis, Artikel, Makalah, Berita, Essei, Dll (Bandung: Yrama Widya, 2001), 122. 
faktor eksternal tidak mempunyai waktu, lingkungan tidak kondusif, terbatasnya wadah pelatihan, kurangnya apresiasi.

1. Faktor internal kendala menulis karya tulis ilmiah meliputi:

Kurangnya motivasi. Segala tindakan harus dilakukan berdasarkan niat. Niat merupakan motivasi dari dalam diri seseorang untuk melakukan suatu kegiatan termasuk kegiatan menulis. Kurangnya motivasi seseorang untuk kegiatan menulis mempengaruhi rendahnya kualitas karyanya, kegiatan menulis tidak dilakukan dengan sunggguh bahkan terkesan terpaksa, kalaupun menghasilkan suatu karya, akan menghasilkan karya asal jadi.

Wawasan yang sempit, tidak memiliki ide, gagasan. Ide muncul karena adanya kemampuan mengalisis suatu fenomena yang terjadi, baik berdasarkan pengalaman pribadi maupun melalui membaca berbagai literatur. Kurangnya gagasan mempengaruhi kesulitan dalam merangkai kata menjadi kalimat, tulisan akan tidak berbobot dan tidak ada hal yang baru dari hasil tulisan. Ide akan berkembang seiring dengan banyaknya informasi yang telah tersimpan dalam memori seseorang. Semakin banyak informasi yang tersimpan di memori semakin luas wawasan dan ide sehingga semakin mudah untuk melakukan kegiatan menulis.

Tidak percaya diri, kurang fokus. Kesulitan untuk memulai sebuah tulisan tidak hanya dialami oleh penulis pemula, namun juga dapat dialami oleh penulis senior. Hambatan yang paling sering dialami oleh penulis pemula kesulitan untuk memulai. Kadang-kadang muncul banyak ide di kepala tetapi ketika akan memulai untuk menulis, ide hilang seketika. Apalagi ketika akan dan atau sedang menulis banyak gangguan pikiran di luar kegiatan menulis sehinga mengganggu konsentrasi untuk menulis. Kalau banyak ide yang telah ditulis tetapi merasa tidak percaya diri untuk dipublikasikan. 
Tidak berbakat. Banyak orang berpendapat menulis itu mudah, kalau banyak membaca maka pasti akan biasa menulis, ternyata banyak membaca belum tentu dapat menuliskan kembali dengan dalam perspektif penulis sendiri. Aktivitas menulis menuntut gabungan antara bakat seseorang dengan kemampuan berbahasa yang dimilikinya, namun setidaknya seseorang harus mempunyai bakat sekecil apapun untuk dikembangkan sebagai dasar untuk memulai menulis. Tentu saja bakat bawaan sejak lahir tetap memerlukan proses pengembangan agar dapat menghasilkan suatu karya.

Kurang menguasai kebahasaan. Kendala kebahasaan sering terjadi ketika merangkai kata-kata menjadi sebuah kalimat yang efektif. Hal ini merupakan kendala besar dalam kegiatan menulis terutama menulis karya tulis ilmiah harus memiliki kesatuan dan keterkaitan antara kalimat yang satu dengan yang lainnya sehingga pesan yang disampaikan dalam tulisan tersebut mudah dipahami oleh pembaca. Kendala kebahasaan yang lainya terbatasnya perbendaharaan kata dan istilah yang dimiliki mengenai topik permasalahan yang akan dan atau sedang ditulis. Sering kali terjadi tulisan terhenti karena kehabisan kata atau kalimat.

Merasa puas sebagai konsumen. Sikap merasa puas menjadi pembaca setia tulisan orang lain menjadi faktor internal seseorang bahkan menjadi kendala untuk melakukan kegiatan menulis. Seseorang beranggapan, untuk apa melakukan kegiatan menulis sementara orang lain telah menulis suatu topik dengan sempurna dan bahkan tulisan orang lain lebih dan mudah dipahami dibandingkan dengan tulis sendiri. Menulis kembali suatu topik dengan perspektif penulis sendiri akan membuang waktu dan energi. Padahal, tidak selamanya tulisan orang lain sesuai dengan kebutuhan pembaca.

Keterbatasan waktu. Setiap orang mempunyai waktu yang sama, sementara bagi orang yang tidak dapat memanfaat waktu dengan baik merasa waktu berlalu begitu saja. Seringkali, seseorang mempunyai waktu yang panjang tetapi tidak dapat menghasilkan 
karya tulis sama sekali, apalagi waktu sepenuhnya disibukkan oleh kegiatan rutinitas di luar kegiatan menulis. Namun, ada juga di dalam kesibukan rutinitas justru dapat menghasilkan banyak karya tulis, tentu saja seorang penulis harus mampu mengelola waktu dengan baik dan kapan harus menulis.

2. Faktor eksternal kendala menulis karya tulis ilmiah meliputi:

Lingkungan tidak kondusif. Lingkungan yang tidak kondusif mempengaruhi kurangnya produktivitas menulis seseorang. Lingkungan yang tidak kondusif misalnya adanya konflik ditempat kerja, lingkungan yang tidak aman dan nyaman, banyaknya pekerjaan sehinga merasa cepat kelelahan. Kondisi tersebut dapat menjadi penghambat untuk melakukan kegiatan menulis.

Terbatasnya wadah pelatihan. Kendala lain yang dihadapi oleh penulis adalah terbatasnya wadah untuk melatih kegiatan menulis. Hal ini terlihat kurangnya kegiatan pelatihan, workshop, dan kegiatan perkumpulan penulis. Melalui wadah pelatihan sebenarnya memberikan kesempatan kepada penulis untuk berbagai pengalaman satu sama lain yang berkaitan kegiatan menulis. Pelatihan akan diajarkan teknik penulisan yang baik dan benar yang sangat bermanfaat bagi pengembangan kemampuan seorang penulis.

Kurangnya apresiasi.Motivasi yang kuat akan menghasilkan karya yang baik, namun kurangnya perhatian dan apresiasi dari pihak institusi dalam hal ini pemerintah, atasan, teman sejawat secara tidak langsung melemahkan keinginan untuk melakukan kegiatan menulis. Apresiasi tidak selama bernilai ekonomis, apresiasi dapat berupa pengakuan atas prestasi, memberikan rasa aman dan nyaman dalam melakukan kegiatan menulis.

\section{c. Mengatasi Kesulitan Menulis Karya Tulis Ilmiah}

Pada dasarnya, jika ingin menjadi penulis yang baik, perlu melakukan tiga hal yaitu 1) membaca yang banyak; 2) mendengarkan dengan baik dan cermat, dan 3) menulis yang 
banyak, jangan terlalu banyak berpikir, langsung saja masuk ke dalam kehangatan kata-kata sensasi bunyi dan warna, dan biarkan pena anda terus menari di sepanjang halaman. ${ }^{23}$

Keterampilan menulis adalah keterampilan yang bersifat mekanistis. Keterampilan itu tidak akan dikuasai hanya melalui teori saja namun harus dilaksanakan melalui latihan dan praktik yang teratur. Kemampuan menulis adalah kesanggupan atau kecakapan seseorang dalam mengungkapkan perasaan yang bekenaan dengan suatu pokok masalah secara tegas, lugas, dan tuntas dengan menggunakan bahasa tulis. ${ }^{24}$ Menulis merupakan suatu keterampilan yang erat sekali dengan membaca, kegiatan menulis dan membaca merupakan suatu kegiatan yang perlu dilakukan secara teratur dan berkesinambungan. ${ }^{25}$

Menulis karya tulis ilmiah memang merupakan suatu pekerjaan yang rumit dan kompleks, serta memerlukan pemikiran yang mendalam. Sungguhpun begitu, semua orang memiliki potensi untuk menghasilkan suatu karya tulis ilmiah tersebut, asalkan ia berani memulai, tidak takut salah, mau belajar terhadap segenap kelemahan dan kesalahan yang ada, rajin membaca, dan tidak malu bertanya kepada orang yang dianggap lebih mampu. ${ }^{26}$

Lebih lanjut, cara mengatasi kesulitan menulis, dengan cara:

1) Mulailah mencoba menulis sejak sekarang jangan membiarkan diri ketika muncul keinginan atua gagasan yang ingin dituangkan ke dalam tulisan.

2) Menetukan sasaran atau batas waktu penulisan.

3) Menghilangkan 'sindrome perfeksionistik' sebagai sikap merasa cepat puas dan membuat tulisan dengan asal jadi.

${ }^{23}$ Nadeak, Wilson, Bagaimana Menjadi Penulis Yang Sukses (Bandung: Sinar Baru Algensindo, 2006), 77.

${ }^{24}$ Hasani, Ihwal menulis, 2.

${ }^{25}$ Djuharie, O. Setiawan and Suherli, Panduan Membuat Karya Tulis : Resensi, Laporan Buku, Skripsi, Tesis, Artikel, Makalah, Berita, Essei, Dll, 125.

${ }^{26}$ Gani, E, Komponen-Komponen Karya Tulis Ilmiah, 7. 
4) Menyakinkan diri mampu melakukan menulis seperti yang dilakukan oleh orang lain.

5) Jangan mudah putus asa jika ada yang mengkritik.

6) Menghindari takut salah.

7) Memahami mekanisme penulisan sebagai suatu proses kreatif. ${ }^{27}$

Menulis karangan memang tidak langsung jadi, sebab menulis merupakan proses kreatif. Proses ini merupakan sebagai konsekuensi pematangan suatu tulisan. Adapun langkah yang tergolong ke dalam proses kreatif, sebagai berikut:

1) Mempersiapkan dengan sering membaca buku-buku dan tulisan atau mengikuti berbagai kegiatan ilmiah.

2) Mengolah informasi yang diperoleh, dengan cara mengolah, memilah-milah, atau membandingkan orang lain atu informasi yang telah terkumpul.

3) Menuangkan gagasan yang ada pada benak ke dalam bentuk tulisan.

4) Melakukan pengoreksian setelah tulisan telah usai untuk menyempurnakan tulisan. ${ }^{28}$

Sementara, Ismail Marahimin dalam bukunya "Menulis Secara Populer" menyatakan hubungan antara membaca dengan menulis sangat erat, untuk dapat 'menulis' harus banyak membaca. Membaca memberikan 'tenaga dalam' yang sangat dibutuhkan seorang penulis, hampir tidak bisa diperoleh dengan cara lain. 'tenaga dalam' sebagai berikut: ${ }^{29}$

Pertama, latar belakang informasi, penulis yang memiliki latar belakang informasi yang luas akan merasa mudah meramu tulisannya dengan berbagai ramuan yang lazim digunakan orang di dalam tulisan, sehingga tulisannya enak dibaca dan menarik.

${ }^{27}$ Djuharie, O. Setiawan and Suherli, Panduan Membuat Karya Tulis : Resensi, Laporan Buku, Skripsi, Tesis, Artikel, Makalah, Berita, Essei, Dll, 122.

${ }_{28}$ Djuharie, O. Setiawan and Suherli, 124-25.

29 Marahimin, Ismail, Menulis Populer (Revisi Ed.) (Jakarta: Dunia Pustaka Jaya, 2001), 6-21. 
Tulisan seperti itu dikatakan mempunyai referensi atau kerangka referensi yang luas yang dilakukan dengan proses membaca. Adhitya Mulya seorang novelis, mengatakan janganlah pernah berhenti haus membaca karena buku mengantarkan kita pengalaman yang dapat kita petik tanpa harus mengalami. ${ }^{30}$ Kata bijak dari KH.Sahal Mahfudz, "seseorang akan mulai menjadi bodoh ketika berhenti membaca" ${ }^{31}$

Kedua, well-rounded man, seorang penulis harus mengetahui serba sedikit mengenai apa saja di dunia ini, di samping pengetahuannya yang luas dan mendalam mengenai bidangnya sendiri. Hal ini dapat dikuasai dengan membaca. Banyak membaca dan dalam beraneka bidang. Wajar, Allah SWT menurunkan perintah pertama kepada Rasulullah SAW yang dianjurkan untuk selalu membaca, sebagai mana yang termaktub dalam QS. Surah Al-Alaq: 1-5, artinya: 1) Bacalah dengan nama Tuhanmu yang maha mencipta, 2) Yang telah menciptakan manusia dari alaq, 3) Bacalah dan Tuhanmu maha pemurah, 4) Yang mengajarkan dengan pena, 5) mengajar manusia apa yang belum diketahui(nya). Menurut Muhammad Abduh, pengulangan penggunaan kata iqra' menunjukan kemampuan membaca dengan lancar dan baik tidak dapat diperoleh dengan tanpa mengulang-ngulangi atau melatih secara teratur. ${ }^{32}$ Selanjutnya, Quraish Shihab menyatakan perintah membaca yang kedua dimaksudkan agar banyak membaca, menelaah, memperhatikan alam raya, serta membaca kitab yang tertulis dan tidak tertulis. ${ }^{33}$ Kata qalam dapat berarti hasil dari penggunaan alat tersebut, yakni tulisan. Pengajaran dapat ditempuh pertama, melalui pena (tulisan) yang harus dibaca oleh manusia dan yang kedua melalui pengajaran secara langsung tanpa alat.

\footnotetext{
${ }^{30}$ A. Mustofa Bisri, The Key Word: Perpustakaan di Mata Masyarakat (Pepustakaan UIN Sunan Kalijaga, 2011), 36.

${ }^{31}$ Bisri, 96.

${ }^{32}$ M. Quraish Shihab, Tafsir al-Mishbah: Pesan, Kesan, dan Keserasian al-Quran (Jakarta: Lentera Hati, 2002), 460.

${ }^{33}$ Shihab, 461.
} 
Ketiga, penulis harus peka terutama kepekaan bahasa, kepekaan materi dan kepekaan tulisan. Kepekaan bahasa yang mencakup tulisan, paragraf, kalimat, arti kata dan sebagainya sehingga tulisan enak dibaca, kalimat enak kedengarannya, kata yang tepat untuk mengambarkan sesuatu. Kepekaan materi dan bentuk yang dimiliki penulis tentu tahu apa-apa yang dapat dituliskan dan tahu bentuk apa yang tepat untuk materi yang akan ditulisnya. Kepekaan ini dapat dimiliki dengan membaca. Bacaan yang banyak dan luas serta mencakup berbagai bidang akan memberikan kepekaan.

Keempat, copy the master, kalau ingin belajar melukis cara Barat, harus belajar garis dan bentuk dulu, kemudian anatomi, perspektif, warna dan sebagainya menurut urut-urutan yang sesuai dengan pendirian guru yang mengajar. Konon, di Cina pada zaman dahulu tidak demikian, orang yang ingin menjadi pelukis akan diberi sebuah lukisan yang sudah jadi dan baik, biasanya dibuat oleh seorang master, yaitu ahli melukis atau pelukis terkenal. Sang calon pelukis disuruh meniru lukisan master tadi sampai sebisa-bisanya, semirip mungkin setelah berkali-kali mencoba, sang murid akan mendapat sebuah master baru untuk ditiru. Begitulah seterusnya sampai calon penulis bisa menulis sendiri dan menemukan bentuk yang khas sesuai dengan keperibadiannya. Metode ini dinamakan copy the master, meniru lukisan seorang ahli. Dalam kegiatan menulis harus melihat model hasil tulisan yang telah ada, dan terus melakukan latihan menulis sesuai dengan model tersebut sampai mengerti dan sanggup membuat tulisan secara baik. Latihan-latihan inilah inti dari segala macam dan bentuk pelajaran menulis.

Kelima, tulis ulang tulisan yang telah dibuat dan dibaca kembali, perhatikan apakah cukup menarik bagi orang lain, tidak menimbulkan multi tafsir, bahkan kalau perlu lakukan dua tiga kali ulang atau lebih, bagaimanapun bagusnya tulisan mula-mula itu, selalu masih dapat diperbaiki sehingga menjadi lebih bagus dan lebih berseni. Dengan demikian akan mengurangi perasaan 
cepat puas, karena perasaan ini menghalangi kemungkinan menjadi penulis.

Jangan khawatir soal bakat atau kemampuan anda, hal itu akan tumbuh seiring dengan latihan. Roshi Katagiri berkata "bakat itu seperti sumber air di bawah tanah" tak seorangpun yang memilikinya, tetapi anda boleh mengambilnya. Anda mengambilnya dengan usaha anda dan dia kan mengalir ke arah anda. Jika anda inginkan adalah esai atau cerita pendek, tulislah. Dalam proses menuliskannya, anda akan belajar bagaimana caranya. Anda bisa percaya bahwa secara perlahan anda akan menguasai teknik dan keterampilan yang anda butuhkan. ${ }^{34}$

\section{Simpulan}

Karya tulis ilmiah adalah karya tulis yang bersifat keilmuan yang disusun secara sistematis menurut kaidah-kaidah tertentu berdasarkan hasil berfikir ilmiah dan metode ilmiah. Adapun kendala dalam melakukan kegiatan menulis dipengaruhi oleh faktor internal mencakup kurangnya motivasi, tidak memiliki ide, tidak percaya diri, kurang fokus, wawasan yang sempit, tidak berbakat, kurang menguasai kebahasaan, merasa puas sebagai konsumen. Sedangkan, faktor eksternal yaitu tidak mempunyai waktu, lingkungan tidak kondusif, terbatasnya wadah pelatihan, kurangnya apresiasi. Namun demikian, keterampilan menulis itu tidak akan dikuasai hanya melalui teori saja tetapi harus dilaksanakan melalui latihan dan praktek yang teratur diimbangi dengan membaca yang banyak, mendengarkan dengan cermat, dan menulis yang banyak.

${ }^{34}$ Nadeak, Wilson, Bagaimana Menjadi Penulis Yang Sukses, 65. 


\section{DAFTAR PUSTAKA}

Bisri, A. Mustofa. The Key Word: Perpustakaan di Mata Masyarakat. Pepustakaan UIN Sunan Kalijaga, 2011.

Djatmika. Menjadi Penulis Untuk Pencerahan Demokrasi. Malang: Bayumedia Publishing, 2004.

Djuharie, O. Setiawan, and Suherli. Panduan Membuat Karya Tulis : Resensi, Laporan Buku, Skripsi, Tesis, Artikel, Makalah, Berita, Essei, Dll. Bandung: Yrama Widya, 2001.

Gani, E. Komponen-Komponen Karya Tulis Ilmiah. Bandung: Pustaka Reka Cipta, 2013.

Hasani, Aceng. Ihwal menulis. Untirta Press, 2005.

Indonesia. Undang-Undang Republik Indonesia Nomor 43 Tahun 2007 Tentang Perpustakaan. Perpustakaan Nasional, 2007.

Marahimin, Ismail. Menulis Populer (Revisi Ed.). Jakarta: Dunia Pustaka Jaya, 2001.

Nadeak, Wilson. Bagaimana Menjadi Penulis Yang Sukses. Bandung: Sinar Baru Algensindo, 2006.

"Peraturan Menteri Pendayagunaan Aparatur Negara Dan Reformasi Birokrasi Republik Indonesia Nomor 9 Tahun 2014 Tentang Jabatan Fungsional Pustakawan Dan Angka Kreditnya," n.d.

"Peraturan Pemerintah Republik Indonesia Nomor 24 Tahun 2014 Tentang Pelaksanaan Undang-Undang Nomor 43 Tahun 2007 Tentang Perpustakaan," n.d.

Perpustakaan Nasional, R. I. "Peraturan Bersama Kepala Perpustakaan Nasional Republik Indonesia Dan Kepala Badan Kepegawaian Negara Nomor 8 Tahun 2014 Nomor 32 Tahun 2014 Tentang Ketentuan Pelaksanaan Peraturan Menteri Pendayagunaan Aparatur Negara Dan Reformasi Birokrasi Republik Indonesia Nomor 9 Tahun 2014 Tentang Jabatan Fungsional Pustakawan Dan Angka Kreditnya," 2014. 
- - - "Peraturan Kepala Perpustakaan Nasional Republik Indonesia Nomor 11 Tahun 2015 Tentang Petunjuk Teknis Jabatan Fungsional Pustakawan Dan Angka Kreditnya," 2015.

Shihab, M. Quraish. Tafsir al-Mishbah: Pesan, Kesan, dan Keserasian al-Qur'an. Jakarta: Lentera Hati, 2002.

Tanjung, Bahdin Nur, and Ardial. Pedoman Penulisan Karya Ilmiah (Proposal, Skipsi, Dan Tesis) Dan Mempersiapkan Diri Menjadi Penulis Artikel Ilmiah. Jakarta: Kencana, 2005.

Tarigan, Henry Guntur. Menulis Sebagai Suatu Keterampilan Berbahasa. Angkasa, 2008. 